\title{
Metabolic responses to environmental salinity in the invasive clam Corbula amurensis
}

\author{
Adam Paganini, Wim J. Kimmerer, Jonathon H. Stillman* \\ Romberg Tiburon Center for Environmental Studies, 3152 Paradise Dr., Tiburon, California 94920, USA
}

\begin{abstract}
Invasive species can have large impacts on food webs if their metabolic demands are higher than those of extant species. The clam Corbula amurensis is believed to have caused a large shift in the pelagic food web in the northern reach of the San Francisco Estuary (USA) since its introduction in the 1980s. This shift has been attributed to the clam's high density, high suspension-feeding rates, and ability to thrive in a wide range of salinities. To understand how environmental salinity alters the potential metabolic impacts of $C$. amurensis on the pelagic food web, we investigated clam metabolism following acclimation to constant low, constant high, and fluctuating salinities. We measured growth rate, feeding rate, respiration rate, activity of the metabolic enzyme malate dehydrogenase (MDH), and osmoregulatory performance. Clams did not grow during a 3 mo period at either high or low salinity, although they fed more rapidly following acclimation to high salinity than low. $C$. amurensis had higher metabolic rates in both high and low salinity than in fluctuating salinities. Activity of MDH was positively correlated with salinity in both foot and mantle tissues. MDH activities of $C$. amurensis were twice those of other clam species. Osmotic pressure of $C$. amurensis tissues was always lower than that in the acclimation water, but clams hyporegulated to a greater extent in high-salinity conditions. Overall, our results suggest that clams experiencing higher salinities increase metabolic rates to support greater osmoregulation and compensate by increasing their filter-feeding rate.
\end{abstract}

KEY WORDS: Corbula $\cdot$ Clam · Metabolism · Salinity $\cdot$ MDH · Osmoregulation · San Francisco Bay · Invasive species Resale or republication not permitted without written consent of the publisher

\section{INTRODUCTION}

Many of the world's freshwater and estuarine ecosystems have been altered in the past century by invasive species (Strayer 2010). The degree to which invasive species disturb existing ecological communities depends on the specific dynamics of food webs characterizing those communities (May 1973). The strength of interactions between an introduced species and the extant community depends in part on the metabolic demands of the invasive species. In particular, altered community dynamics may occur when the introduced species is at a low trophic level (e.g. primary consumer). In this study, we investigated the metabolic demands of an invasive estuarine filter-feeding bivalve mollusk under conditions of varying salinity.

The overbite clam Corbula amurensis was first discovered in the San Francisco Estuary (SFE), USA, in October 1986, and reached densities exceeding $10000 \mathrm{~m}^{-2}$ within 2 yr (Carlton et al. 1990). By 1990, C. amurensis was a dominant species in benthic communities throughout the estuary at a wide range of salinities and temperatures (Nichols et al. 1990). Filterfeeding by $C$. amurensis has been linked to a reduction in summertime phytoplankton abundance in the shallow brackish northern reaches of the SFE (Alpine \& Cloern 1992). In addition to phytoplankton, C. amurensis is capable of grazing on bacterioplankton (Werner \& Hollibaugh 1993) and copepod nauplii (Kimmerer et al. 1994), and is thus able to graze on the entire base of the food web. A decline in abundance of 3 common estuarine copepod species coincided with the invasion of $C$. amurensis, probably through a combination of predation and competition for food in the form of phytoplankton and microzooplankton (Kimmerer \& Orsi 1996). Concurrent declines occurred in abun- 
dances of other pelagic taxa including mysid shrimp Neomysis mercedis (Orsi \& Mecum 1996), longfin smelt Spirinchus thaleichthys (Kimmerer 2002a), and striped bass Morone saxatilis (Kimmerer et al. 2009), all presumably due to food limitation. Furthermore, food limitation has probably played a role in the continuing decline of these and other estuarine fish species (Feyrer et al. 2007, Sommer et al. 2007).

Salinity patterns in the upper estuary respond strongly to freshwater flow, and climate shifts and water management practices in the Sacramento-San Joaquin Delta alter the seasonal and interannual patterns of flow (Roos 1989, Knowles \& Cayan 2002, Kimmerer 2002b). Furthermore, a large area of subsided farmland in the delta, poorly protected by weak levees, may catastrophically flood, shifting the salinity field far to landward (Mount \& Twiss 2005). Shifts in the salinity field are likely to affect freshwater supplies and alter the distributions of key estuarine species, and are therefore of key interest for management (Moyle 2008).

Rapid and substantial fluctuations in salinity can force physiological responses of estuarine organisms such as Corbula amurensis. Chaparro et al. (2008) showed that the suspension-feeding gastropod Crepipatella dilatata slows and eventually ceases filtration at salinities below 20. During exposure to reduced salinity, the bivalve filter feeder Argopecten purpuratus lowers clearance and ingestion rates (FernándezReiriz et al. 2005). Reduction of digestive enzyme activity has also been observed in A. purpuratus during hyposmotic stress (Fernández-Reiriz et al. 2005).

Energetic requirements imposed by varying environmental salinity on Corbula amurensis may alter their energy demand and therefore the impact of these clams on the pelagic food web. Thus, understanding the energetic consequences of environmental salinity in C. amurensis is a key to developing ecological models of predicting the impact of this species under different salinity scenarios. To determine how the energetics of these clams may vary with the salinity regime, we investigated metabolic rate, metabolic enzyme activity, filtration rate, and osmoregulation of this species acclimated at several salinities, including both constant and fluctuating salinities.

\section{MATERIALS AND METHODS}

Specimen collection and maintenance. Corbula amurensis were collected by dredge in November 2008 from Spoonbill Creek in North San Pablo Bay $\left(38^{\circ} 5^{\prime} 10^{\prime \prime} \mathrm{N}\right.$, $122^{\circ} 1^{\prime} 40^{\prime \prime} \mathrm{W}$ ) where salinity at time of collection was 13. Clams were acclimated for 4 to $8 \mathrm{wk}$ in $10 \mathrm{l}$ aquaria to 3 different salinities: 2 (low), 28 (high), or 4 to 14 (fluctuating) at $15^{\circ} \mathrm{C}$. Clam valve lengths, heights, and widths ranged from 13.1 to $19.3 \mathrm{~mm}, 8.0$ to $11.2 \mathrm{~mm}$, and 4.0 to $6.6 \mathrm{~mm}$, respectively, using clam morphometric nomenclature of Gaspar et al. (2002).

Salinity fluctuations from salinities of 4 to 14 at $12 \mathrm{~h}$ intervals were produced by alternately pumping COMBO artificial fresh water (Kilham et al. 1998) and synthetic seawater (Seachem ReefSalt) into aquaria. Water for constant salinity acclimation treatments at salinity of 2 and a salinity of 28 was seawater diluted with $\mathrm{COMBO}$. Clams were fed Shellfish Diet $^{\circledR}$ (www. Shellfish-Diet.com) to chlorophyll a (chl a) concentrations of 100 to $120 \mathrm{\mu g} \mathrm{l}^{-1}$ every other day. This concentration is equivalent to the historical upper limit of phytoplankton biomass in the northern SFE (Arthur \& Ball 1979). Shellfish Diet ${ }^{\complement}$ is a mixture of 4 marine microalgae (30\% Isochrysis, $20 \%$ Pavlova, $20 \%$ Tetraselmis, and $30 \%$ Thalassiosira weissflogii), each of which can be used to rear a variety of mollusks including oysters, clams, mussels, and scallops. To compare metabolic enzyme activities of Corbula amurensis to other common bivalves, Manila clam Venerupis philippinarum and cherrystone clam Mercenaria mercenaria were purchased from a San Francisco seafood market and acclimated to a salinity of 28 for 4 to $8 \mathrm{wk}$.

Whole organism physiology. To determine growth rate, clam shell dimensions (length, width, and height) were measured weekly for 15 wk in 10 clams treatment $^{-1}$ at $10 \mu \mathrm{m}$ precision using Fisherbrand digital traceable calipers. Clam weight in shell, wet tissue mass, and dry tissue mass were determined for a large number of clams to assess the relationship among these variables (Fig. 1), specifically whether shell density or thickness differed among acclimation groups.

Clearance rate was measured by placing individual clams in $30 \mathrm{ml}$ jars with $23 \mathrm{ml}$ of corresponding acclimation water at 14 to $15^{\circ} \mathrm{C}$ and $12 \mathrm{~g}$ of crushed coral sand (Aragamax, Brand Carib Sea). Sand was used because growth has been shown to be greatest in sediments with 70 to $80 \%$ sand, and slower in soft muds (Carlton et al. 1990). Clams exhibited typical behavior: they siphoned, burrowed, and searched for substrate in the Aragamax sand. A small water volume of $23 \mathrm{ml}$ was used in clearance rate experiments so that a large decrease in chl a would be observed over a short experimental duration. Water was mixed with gentle aeration to keep food suspended and homogeneous. Shellfish $\operatorname{Diet}^{\odot}$ was added to a final density of $300 \pm$ $10 \mu \mathrm{g} \mathrm{l}^{-1} \mathrm{chl} a$ in each jar. Nine percent of the volume of Shellfish Diet ${ }^{\odot}$ is dry weight (www.Shellfish-Diet. com). Light microscopy was used to verify that phytoplankton cells in Shellfish Diet ${ }^{\odot}$ did not lyse at any of the experimental salinities. Phytoplankton relative fluorescence (RFU) measured at 10 min intervals for $80 \mathrm{~min}$ did not differ between salinity of 2 and 28 (mean $\pm \mathrm{SD}=37436 \pm 1395$ and $37146 \pm 777$ respec- 

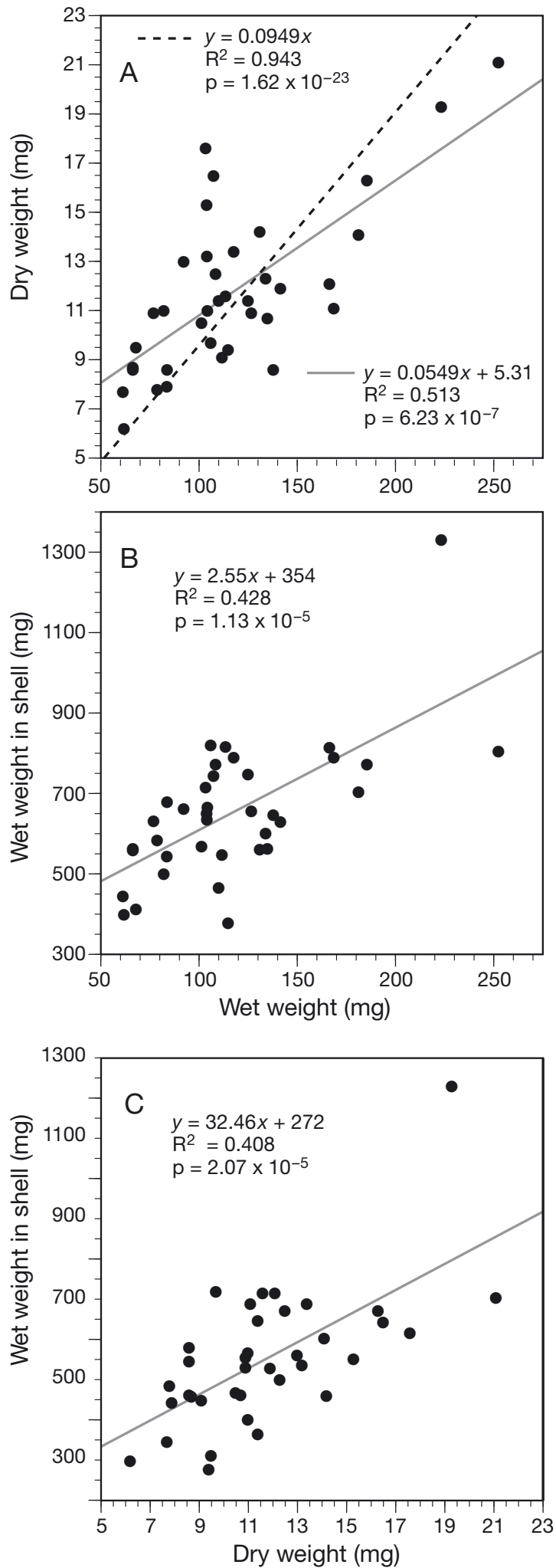

Fig. 1. Corbula amurensis. Correlation and regression analyses of mass measurements. (A) Dry weights vs. wet weights, (B) weight in shell vs. wet weight, and (C) weight in shell vs. dry weight. All equations expressed in units of $10^{-3} \mathrm{~g}$. In (A), dashed line represents regression through the origin tively; $t$-test, $\mathrm{p}=0.59)$. Water samples of $110 \mu \mathrm{l}$ were taken from each jar every $10 \mathrm{~min}$ for $60 \mathrm{~min}$ and placed into wells of a Corning flat black 96-well microplate. Fluorescence of chl a was measured with a Tecan Infinite 200 microplate spectrophotometer using $480 \mathrm{~nm}$ excitation and $680 \mathrm{~nm}$ emission filters. The experimental duration of 60 min resulted in sufficient reductions in chl a to get a representative feeding response (Fig. 2). Clearance rates were calculated as:

$$
F_{i}=\left(b_{C}-b_{i}\right) V / W
$$

where $F_{i}$ is clearance rate $\left(\mathrm{l} \mathrm{g}^{-1} \mathrm{~h}^{-1}\right)$ for clam $i, b_{C}$ is the mean slope of $\ln$ fluorescence versus time in the controls, $b_{i}$ is the slope of ln fluorescence versus time for clam $i, V$ is water volume (l), and $W$ is dry weight of the clam (g). Clams were weighed in shell, wet tissues were dissected and weighed, and then tissues were dried and weighed again. Linear regression models were used to estimate dry weights from wet weights (Fig. 1). This model was used to determine dry mass when only wet weights were available.

Respiration rate was determined at $15^{\circ} \mathrm{C}$ using a single-valve differential manometric respirometer (Gilson International). Clams were placed in individual $20 \mathrm{ml}$ respirometry flasks with $11 \mathrm{ml}$ of corresponding acclimation water and $9 \mathrm{ml}$ air. Each flask housed a side compartment in which a $2 \mathrm{~cm}$ long piece of filter paper was placed to wick from a reservoir containing $0.6 \mathrm{ml}$ of $3 \mathrm{M} \mathrm{KOH}$ to scrub gaseous $\mathrm{CO}_{2}$. Respiration rates for each individual were measured in triplicate $90 \mathrm{~min}$ assays, with consumption of $\mathrm{O}_{2}$ measured at $15 \mathrm{~min}$ intervals during each assay. Oxygen consumption rates were calculated as $\mu \mathrm{mol} \mathrm{O}_{2} \mathrm{~h}^{-1} \mathrm{~g}$ dry weight ${ }^{-1}$.

Sub-organismal physiology. Malate dehydrogenase $(\mathrm{MDH})$ is a metabolic enzyme that plays critical roles in a variety of metabolic pathways (Goward \& Nicholls 1994) and is correlated with overall metabolism in mussels (Dahlhoff et al. 2002). Activity of the MDH was determined following Siebenaller \& Somero (1982) in mantle and foot tissues from 8 Corbula amurensis per salinity acclimation treatment, as well as from Venerupis philippinarum and Mercenaria mercenaria. Mantle was chosen because it is an osmoregulatory tissue in bivalve mollusks (Deaton 1987, 1992), and foot because it is actively used during burrowing and maintenance of position. Each tissue sample was homogenized in Kontes-Duall ground glass homogenizers in 29 volumes (weight volume ${ }^{-1}$ ) of $50 \mathrm{mM}$ potassium phosphate buffer and centrifuged for $15 \mathrm{~min}$ at $16000 \times \mathrm{g}$. Five $\mu \mathrm{l}$ of tissue homogenate was added to wells of a Corning flat black 96-well microplate and inserted into a Tecan Infinite 200 Microplate Spectrophotometer. Using an automatic injection system, $200 \mu \mathrm{l}$ of $\mathrm{MDH}$ assay cocktail (200 mM imidazole/Cl pH 7.2, $0.15 \mathrm{mM}$ $\mathrm{NADH}$, and $0.2 \mathrm{mM}$ oxaloacetate) was injected into 
each well. Absorbance of NADH was followed at $340 \mathrm{~nm}$ for 1 to $2 \mathrm{~min}$, and temperature was held constant at $25^{\circ} \mathrm{C}$. MDH activity ( $\mu$ mol oxaloacetate oxidized $\mathrm{min}^{-1}$ ) is expressed in international units (IU) $\mathrm{g}^{-1}$ fresh weight (FW).

Osmolarity of clam tissues was determined by dissecting whole clams and homogenizing in 5-fold dilutions of deionised $\mathrm{H}_{2} \mathrm{O}$ with Kontes-Duall ground glass homogenizers. Ten $\mu \mathrm{l}$ of homogenate was used to determine osmolarity using an Osmette freeze-point depression osmometer. Osmolarity of the acclimation water was also determined by the same method.

$\mathrm{Na}^{+} / \mathrm{K}^{+}$ATPase is an enzyme that controls the membrane-bound $\mathrm{Na}^{+} / \mathrm{K}^{+}$ion pump and therefore controls the cell's ion concentration, or its osmolarity. Mantle tissue was dissected from clams and homogenized in Kontes-Duall ground glass homogenizers in a 15 -fold dilution of $50 \mathrm{mM}$ Imidazole/Cl, pH 7.3, $20 \mathrm{mM}$ $\mathrm{Na}_{2}$ EDTA, and $300 \mathrm{mM}$ sucrose buffer, and centrifuged for 2 min at $16000 \times g$ to remove large particles. Assays were performed in a Corning flat black 96-well microplate using a Tecan Infinite 200 Microplate Spectrophotometer at $25^{\circ} \mathrm{C}$. Six wells sample ${ }^{-1}$ were prepared in which $5 \mu$ supernatant was placed in each well, 3 wells had $40 \mu \mathrm{l}$ of $10 \mathrm{mM}$ ouabain, a specific inhibitor of $\mathrm{Na}^{+} / \mathrm{K}^{+}$ATPase (Hilden \& Hokin 1976), and 3 wells had $40 \mu \mathrm{H}_{2} \mathrm{O}$. To each well we added $200 \mu \mathrm{l}$ of $\mathrm{Na}^{+} / \mathrm{K}^{+}$ATPase assay cocktail containing $148 \mathrm{mM} \mathrm{NaCl}, 23.7 \mathrm{mM} \mathrm{KCl}, 7.74 \mathrm{mM} \mathrm{MgCl}_{2}$, $35.5 \mathrm{mM}$ imidazole, $0.59 \mathrm{mM}$ EGTA, $0.47 \mathrm{mM} \mathrm{KCN}$, $\mathrm{pH} 7.25,22.5 \mathrm{mM} \mathrm{Na}_{2} \mathrm{ATP}, 4.5 \mathrm{mM} \mathrm{Na}_{2} \mathrm{NADH}_{1} 45 \mathrm{mM}$ phosphoenolpyruvate mono cyclohexyl ammonium salt, $67.5 \mathrm{U} \mathrm{ml}^{-1}$ pyruvate kinase enzyme (Sigma P1381$10 \mathrm{KU})$, and $45 \mathrm{U} \mathrm{ml}^{-1}$ lactate dehydrogenase enzyme

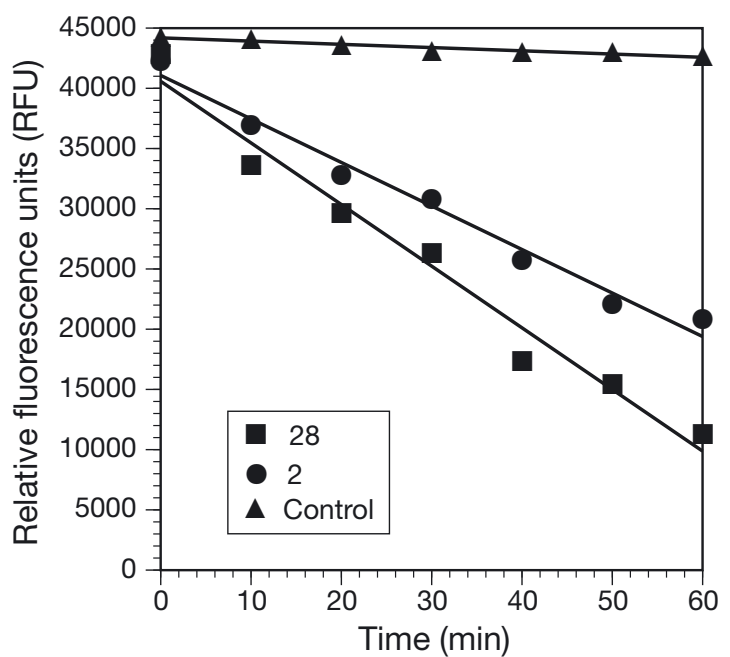

Fig. 2. Examples of raw data acquired from clearance rate experiments. Salinity 28: $f_{(\mathrm{x})}=-511.7 x+40589, \mathrm{r}^{2}=0.97$; salinity 2: $f_{(\mathrm{x})}=-361.1 \mathrm{x}+41070, \mathrm{r}^{2}=0.98$; no clam control: $f_{(\mathrm{x})}=-26.8 \mathrm{x}$ $+44191, r^{2}=0.92$
(Sigma L2625-2.5KU). Oxidation of NADH was monitored at $340 \mathrm{~nm}$ for approximately $30 \mathrm{~min}$.

Statistical analyses were conducted in Microsoft Office Excel version 2007 for Windows and SPSS version 15. Regressions for clearance rate analysis were conducted in MATLAB version 5. In the text, data are presented as means $\pm 95 \%$ confidence intervals unless otherwise noted.

\section{RESULTS}

\section{Whole organism physiology}

We did not observe an effect of acclimation salinity on growth rate over any of the 3 shell size metrics. Shell length, width, and height did not increase over the course of our study.

Clams acclimated to high salinity cleared $2.2 \pm 1.0 \mathrm{l}$ $\mathrm{h}^{-1} \mathrm{~g}^{-1}$ dry weight (DW), while clams acclimated to low salinity cleared $0.9 \pm 0.51 \mathrm{~h}^{-1} \mathrm{~g}^{-1} \mathrm{DW}$, about $41 \%$ of the rate at high salinity ( $t$-test, $\mathrm{p}<0.05$, Fig. 3 ).

Clams acclimated to high salinity did not show significantly higher oxygen consumption rates $\left(\mathrm{VO}_{2}, 41 \pm\right.$ $10 \mu \mathrm{mol} \mathrm{O} \mathrm{h}^{-1} \mathrm{~g}^{-1} \mathrm{DW}, \mathrm{n}=8$ ) compared to clams in the low-salinity acclimation group $\left(34.4 \pm 2.2 \mu \mathrm{mol} \mathrm{O} \mathrm{O} \mathrm{h}^{-1}\right.$ $\mathrm{g}^{-1} \mathrm{DW}, \mathrm{n}=8$, ANOVA, $\mathrm{p}=0.2$; Fig. 4). Clams in fluctuating salinity had $40 \%$ lower $\mathrm{VO}_{2}\left(25.6 \pm 5.3 \mu \mathrm{mol} \mathrm{O} \mathrm{O}_{2}\right.$ $\mathrm{h}^{-1} \mathrm{~g}^{-1} \mathrm{DW}, \mathrm{n}=7$ ) than both low and high salinity acclimation groups, except for 1 outlier individual (ANOVA with outlier removed, $\mathrm{p}<0.01$; Fig. 4). $\mathrm{VO}_{2}$ of 1 clam in the fluctuating salinity group far exceeded that of any of the other specimens in all salinity acclimation groups $\left(617 \mu \mathrm{mol} \mathrm{O} \mathrm{h}^{-1} \mathrm{~g}^{-1} \mathrm{DW}\right.$, Fig. 4). We

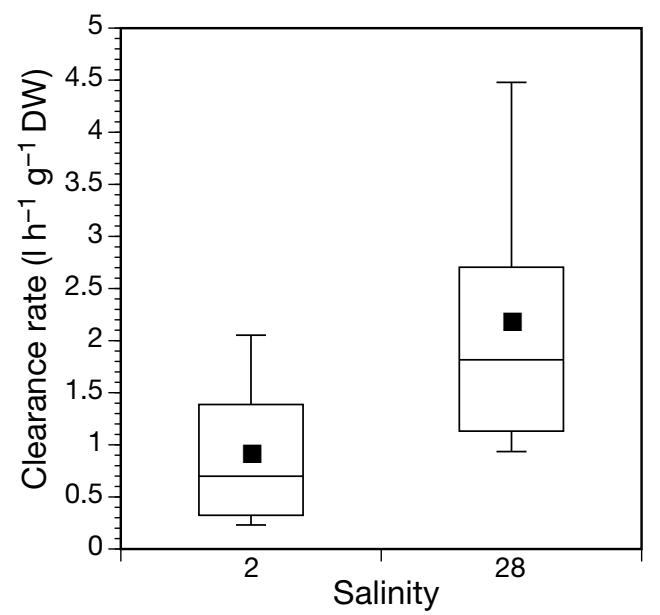

Fig. 3. Corbula amurensis. Clearance rates of clams acclimated to salinities of 2 and 28. Boxplots represent mean (dot), median (line), quartiles (box), and high and low values (top and bottom bars). The mean clearance rate at high salinity was about twice that at low $(t$-test, $\mathrm{df}=1, \mathrm{p}<0.05)$ 
could not identify any reason to suggest an external disturbance or other factor that could have caused a spuriously high metabolic rate. This clam behaved similarly and was of similar size class to the other clams. In addition, other clams tested in that particular respirometer channel had $\mathrm{VO}_{2} \mathrm{~s}$ that were not outliers. We conclude that this was a genuinely high value showing a capability of at least some clams to respire at extraordinary rates.

\section{Sub-organismal physiology}

Clams hyporegulated osmotic content regardless of acclimation salinity, but the degree of regulation was greater at high salinity (Table 1). Tissue osmolarity of lowsalinity clams was 3.4 times lower than that of the water, while tissue osmolarity in the high-salinity group was 8.2 times lower than that of the water (ANOVA, df $=1$, p < 0.001; Table 1).

We were unable to determine the fraction of total ATPase activity attributable to the $\mathrm{Na}^{+} / \mathrm{K}^{+}$ATPase using inhibition by ouabain or by using a $\mathrm{K}^{+}$-free assay cocktail. Total ATPase activity was $5.9 \pm 0.6 \mu$ mol ATP $\mathrm{min}^{-1} \mathrm{~g}^{-1}$ for the low salintiy clams and $3.1 \pm 0.9 \mu \mathrm{mol}$ ATP min $^{-1} \mathrm{~g}^{-1} \mathrm{FW}$ for the high salinity clams, but total ATPase activity was unchanged in the presence of the inhibitor. Thus, it is possible that Corbula amurensis osmoregulatory ion pumps are ouabain insensitive, or that the activities of osmoregulatory ion pumps were too low to measure using the enzyme-coupled spectrophotometric activity assay method.

MDH activity of Corbula amurensis foot tissue ranged from 270 to $325 \mu \mathrm{mol}$ oxaloacetate oxidized $\mathrm{min}^{-1} \mathrm{~g}^{-1}$ FW with an $18 \%$ change in activity from low salinity to high salinity (Fig. 5, ANOVA, p < 0.05). There was no significant difference in foot $\mathrm{MDH}$ activity between $C$. amurensis acclimated to fluctuating salinity and clams acclimated to either low or high constant salinity (Fig. 4). MDH activity in mantle tissue ranged from 94 to $152 \mu \mathrm{mol}$ oxaloacetate oxidized $\mathrm{min}^{-1} \mathrm{~g}^{-1} \mathrm{DW}$ with a $38 \%$ increase in activity from low salinity to high salinity (ANOVA, p < 0.001). Clams acclimated to high salinity had significantly higher mantle MDH activity than did clams in either of the other salinity acclimation groups (ANOVA, Tukey's HSD, df $=2$, p < 0.01). Foot tissue assayed from all clams always had higher MDH activity than the mantle tissues, but mantle tissue had lower variance within groups and differences could be seen more clearly between treatment groups.
Table 1. Corbula amurensis. Osmotic content (mOsm $\mathrm{l}^{-1} \pm$ $1 \mathrm{SD}$ ) of tissue and acclimation tank water at 2 different salinities

\begin{tabular}{|lccc|}
\hline Salinity & Clams $(\mathrm{n}=5)$ & Water & Water:clam ratio \\
\hline 2 & $31.0 \pm 5.4$ & 108 & 3.4 \\
28 & $99.2 \pm 25.6$ & 815 & 8.2 \\
\hline
\end{tabular}

Activities in foot tissue of the 2 other species assayed in this study, Venerupis philippinarum and Mercenaria mercenaria, were $175 \pm 27$ and $167 \pm 29 \mu$ mol oxaloacetate oxidized $\min ^{-1} \mathrm{~g}^{-1} \mathrm{FW}$, respectively. C. amurensis, in all treatments, showed higher MDH activities than other organisms assayed in this and other studies (Table 2).

\section{DISCUSSION}

Our results indicate that the invasive clam Corbula amurensis has metabolic demands that positively correlate to environmental salinity. This implies greater scope for growth and energetic reserves for clams at low salinity, and higher feeding rate at high salinity. In studies of $C$. amurensis ammonium excretion rates 

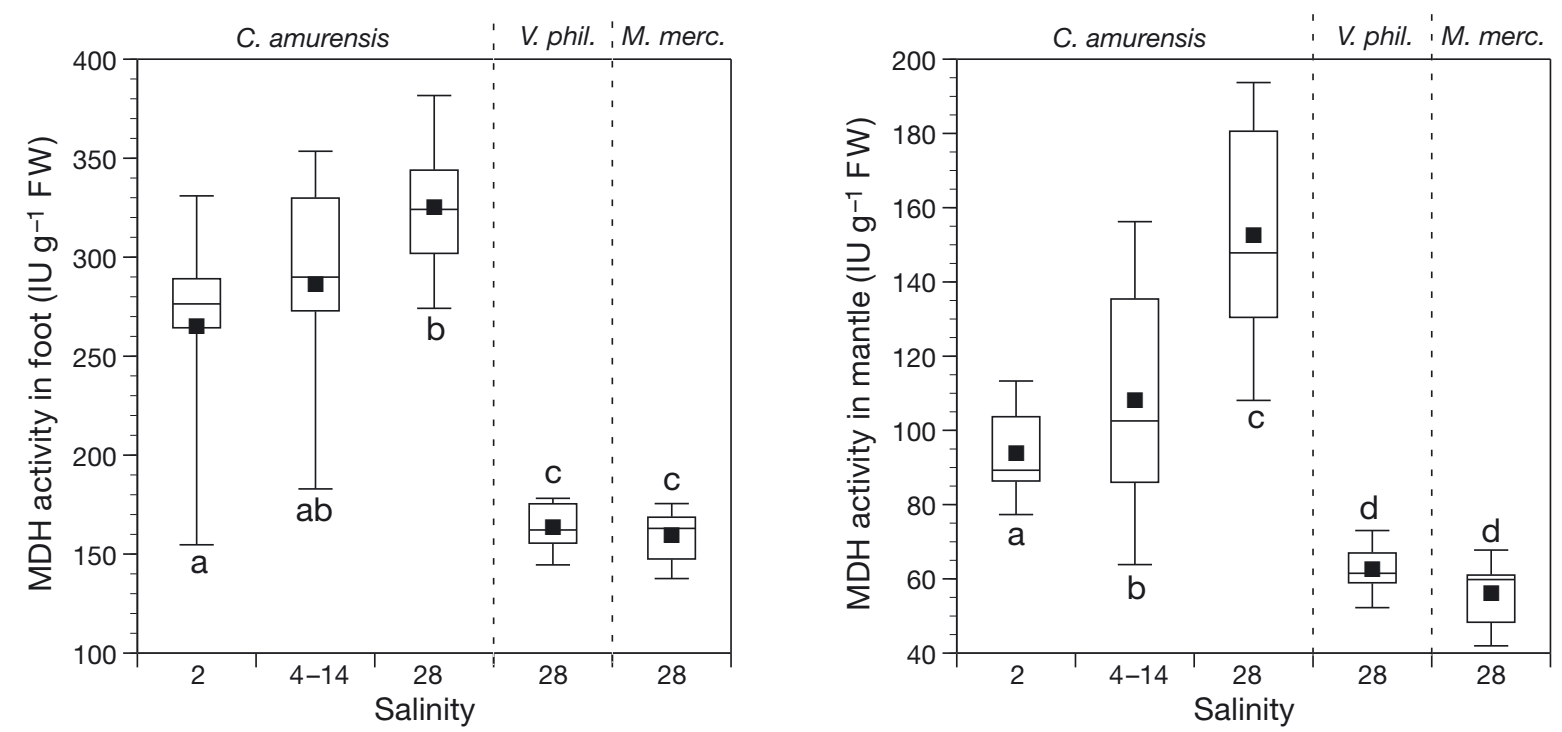

Fig. 5. Malate dehydrogenase (MDH) activity in tissues of overbite clams Corbula amurensis at different acclimation salinities and in 2 other clam species (Mercenaria mercenaria and Venerupis philippinarum), acclimated to high salinity. Boxplots drawn as in Fig. 3. Activity ( $\mu \mathrm{mol}$ oxaloacetate oxidized $\mathrm{min}^{-1}$ ) expressed in International Units (IU) per g fresh weight. Different lowercase letter assignments indicate a significant difference in activity. Differences among mantle tissues based on Tukey's HSD (df $=2$, $\mathrm{p}<0.001)$ and differences among foot tissues based on Dunnett's $(\mathrm{df}=2, \mathrm{p}<0.05)$. Species-wise comparison of MDH activities shows higher activities in C. amurensis than in M. mercenaria or $V$. philippinarum (ANOVA, $\mathrm{df}=2, \mathrm{p}<0.05$ )

$\left(V_{\text {excr }} \mathrm{NH}_{4} ;\right.$ V. Greene, A. Kleckner \& J. H. Stillman unpubl. data), food-limited clams had elevated $V_{\text {excr }}$ $\mathrm{NH}_{4}$ potentially due to the metabolism of body protein for ATP production. This suggests that if clam metabolic demands increased without concomitant increases in feeding rate, these clams would likely have smaller biomass and protein content. Projections based on sea level rise and potential loss of levees in the upper SFE indicate greater penetration of salinity into the estuary in the future (e.g. Knowles \& Cayan 2002, Mount \& Twiss 2005). This will result in a greater area of shallow water at high salinity, where the higher metabolic demands for clam homeostasis may result in a higher filtration impact. At the same time, the spatial-temporal pattern of settlement and retreat of clams at the low-salinity limit of their distribution will depend on their energy reserves and ability to withstand periods of freshwater inundation.

Clams did not grow during the 15 wk over which measurements were taken. Clam sizes ranged from 13 to $19 \mathrm{~mm}$, which is close to the largest shell sizes commonly observed in the northern SFE (Carlton et al. 1990), and could imply that the clams may have reached their maximum size and therefore were no longer growing. Clams in this study were collected in late fall when they are at their largest size, thus sea-

Table 2. Malate dehydrogenase (MDH) activity of Corbula amurensis, additional clam species, and fish muscle. Activity ( $\mu$ mol oxaloacetate oxidized $\mathrm{min}^{-1}$ ) expressed as International Units per gram fresh weight. A range of values indicates that MDH activity at $25^{\circ} \mathrm{C}$ was calculated using $Q_{10}=2$ and $Q_{10}=3$. na: not applicable

\begin{tabular}{|lccccc|}
\hline Species & Tissue & $\begin{array}{c}\text { Original assay } \\
\text { temp }\left({ }^{\circ} \mathrm{C}\right)\end{array}$ & $\begin{array}{c}\text { Original MDH } \\
\text { activity }\end{array}$ & $\begin{array}{c}\text { MDH } \\
\text { activity }\end{array}$ & Source \\
\hline Corbula amurensis (bivalve) & Foot & 25 & na & 325 & Present study \\
Corbula amurensis (bivalve) & Mantle & 25 & na & 153 & Present study \\
Venerupis philippinarum (bivalve) & Foot & 25 & na & 175 & Present study \\
Venerupis philippinarum (bivalve) & Mantle & 25 & na & 63 & Present study \\
Mercenaria mercenaria (bivalve) & Foot & 25 & na & 167 & Present study \\
Mercenaria mercenaria (bivalve) & Mantle & 25 & na & 61 & Present study \\
Mytilus californianus (bivalve) & Mantle & 25 & na & $41-71$ & Dahlhoff et al. (2002), \\
& & & & & Stillman et al. (1996) \\
Diplodon chilensis (bivalve) & Foot & 20 & 163.3 & $231-283$ & Grandón et al. (2008) \\
Diplodon chilensis (bivalve) & Mantle & 20 & 62.57 & $89-108$ & González et al. (2008) \\
Calyptogena gallardoi (bivalve) & Foot & 20 & 89.9 & $253-465$ & Childress \& Somero (1979) \\
Vinciguerria lucetia (mesopelagic fish) & White muscle & 10 & & &
\end{tabular}


sonal or life-history growth cessation is a possibility. If the clams in this study did have a programmed growth cessation, then the energetic needs of these clams would be less than that of actively growing clams. An alternative energetic explanation for the lack of growth observed in our study is that clams in the acclimation aquaria may have been food-limited and thus were unable to partition energy towards growth once energetic demands for basic cellular functions and osmoregulation had been allocated. Clams were fed Shellfish Diet $^{\circledR}$ to chl a concentrations equivalent to some of the highest chl a values recorded in the Suisun Bay (Arthur \& Ball 1979). Since clams were fed every other day, addition of more food to the clam acclimation tanks may have given the clams additional energy required for growth. However, feeding had to be limited to minimize water fouling in the small acclimation aquaria. Shell deposition may have been restricted by unfavorable water chemistry (e.g. low calcite saturation) in the acclimation aquaria. We did not measure parameters of water chemistry such as dissolved inorganic carbon, alkalinity, or calcium ion concentration. However, the clams were held in aragonitic calcium carbonate sand, which has a more sensitive carbonate dissolution threshold than the calcitic calcium carbonate of bivalve shells (Feely et al. 2009). Thus, the sand would have dissolved preferentially to Corbula amurensis shells, and that dissolution would have maintained high alkalinity and calcium ion content in the water.

The increase of clearance rate of Corbula amurensis with salinity (Fig. 3) follows from other studies of marine and freshwater mollusks. In marine mollusks, reduced environmental salinity can reduce feeding rates. For example, the suspension-feeding gastropod Crepipatella dilatata reduced filtration rates by $31 \%$ from a salinity of 25 to 22.5, and stopped filtration when salinity decreased to 20 (Chaparro et al. 2008). The filter-feeding scallop Argopecten purpuratus (Fernández-Reiriz et al. 2005) slows and ultimately ceases filtration in brackish water. In the euryhaline mussel Choromytilus chorus, filtration rates were highest between salinities of 24 and $30(\sim 1.51$ $\left.\mathrm{h}^{-1} \mathrm{~g}^{-1} \mathrm{DW}\right)$, decreased by $62 \%$ to $0.6 \mathrm{l} \mathrm{h}^{-1} \mathrm{~g}^{-1} \mathrm{DW}$ at a salinity of 18 and decreased by $96 \%$ to $0.06 \mathrm{l} \mathrm{h}^{-1} \mathrm{~g}^{-1} \mathrm{DW}$ at a salinity of 15 (Navarro 1988). Other euryhaline estuarine clams such as Mactra veneriformis, Venerupis philippinarum, and Meretrix lusoria have shown that clearance rates are reduced below a salinity of 10 where significant decreases in clearance and growth rates occur (Nakamura et al. 2005). Our results indicate that $C$. amurensis is less sensitive to salinity as it can not only maintain high clearance rates but also active filtration in salinity that ranges from at least $2\left(0.9 \pm 0.5 \mathrm{l} \mathrm{h}^{-1} \mathrm{~g}^{-1} \mathrm{DW}\right)$ to $28\left(2.2 \pm 1.0 \mathrm{l} \mathrm{h}^{-1} \mathrm{~g}^{-1} \mathrm{DW}\right)$ with a $53 \%$ change in clearance rate across that range (Fig. 3), allowing C. amurensis to thrive in a wide range of salinities.
Clearance rates observed for Corbula amurensis in our study were much lower than the range of rates determined previously for similar size specimens of C. amurensis held under laboratory conditions but not under conditions of controlled salinity, viz. 4.8 to $17.8 \mathrm{l} \mathrm{h}^{-1} \mathrm{~g}^{-1} \mathrm{DW}$ (Werner \& Hollibaugh 1993). This may indicate that our clams had reached maximum size by the time acclimation began and the demand for food intake was not as large as that of a growing clam in the field; juvenile clams could require more food per unit biomass and therefore would filter at higher rates.

Osmotic response of Corbula amurensis to both high and low salinity indicates that these clams are hyposmoregulators over a wide range of environmental salinity (Table 1), and that they likely expend more energy in osmoregulation when exposed to higher salinity. Strong metabolic responses to environmental salinity variability have been demonstrated in specimens of Venerupis philippinarum in which oxygen consumption rate decreased initially by $75 \%$ during salinity transitions from salinities of 31 to 10 (Kim et al. 2001). Yet, in our lab study, C. amurensis did not show an apparent decrease in oxygen consumption from high to low salinity. Nakamura et al. (2005) warned that field observations suggest that Mactra veneriformis is the most vulnerable to salinity stress and Meretrix lusoria the most tolerant to low-salinity water, whereas the opposite ranking of salinity tolerance is observed in laboratory experiments. Such inconsistency in response to salinity between field and laboratory results has also been reported in mussels (Gardner \& Thompson 2001).

Overall respiration rates of Corbula amurensis were comparable to those of other bivalve mollusks. The deposit-feeding estuarine bivalve Macoma balthica has respiration rates ranging from 16.6 to $37.4 \mu \mathrm{mol} \mathrm{O}_{2}$ $\mathrm{h}^{-1} \mathrm{~g}^{-1}$ DW (Hummel et al. 2000) and maximal metabolic rates of the Pacific oyster Crassostrea gigas have been measured at $34 \mu \mathrm{mol} \mathrm{O} \mathrm{h}^{-1} \mathrm{~g}^{-1}$ DW (Mao et al. 2006), both within the range of rates for $C$. amurensis (Fig. 4).

$\mathrm{MDH}$ activities indicate that the potential for elevated metabolism increased more with salinity in mantle tissue than in foot tissue (Fig. 5). MDH activity represents metabolic potential in the sense that it demonstrates what the cellular machinery is capable of at maximum flux; therefore $\mathrm{MDH}$ data illustrate the positive correlation between osmoregulatory energetics and demand for maximal metabolic flux. Higher absolute MDH activities in foot tissue indicate that the foot is a more metabolically demanding tissue than mantle tissue (Fig. 5), yet the energetic costs of salinity acclimation were observed in mantle, an important osmoregulatory tissue of clams, where nearly 2-fold 
increases in MDH activity were detected across salinity acclimation treatments. Corbula amurensis had higher MDH activities in both tissues than the other clam species that we examined, Mercenaria mercenaria and Venerupis philippinarum (Fig. 5), suggesting that $C$. amurensis has a higher metabolic flux capacity compared to other clam species. By contrast, in the vesicomyid clam Calyptogena gallardoi, which is known to have a high metabolic rate, foot $\mathrm{MDH}$ activities fell within the range of 88 to $108 \mu \mathrm{mol}$ oxaloacetate oxidized $\min ^{-1} \mathrm{~g}^{-1} \mathrm{FW}$ (Table 2, González et al. 2008), approximately one-third to one-fourth of the $\mathrm{MDH}$ activity in C. amurensis foot tissue (Fig. 5). Foot $\mathrm{MDH}$ activities of $C$. amurensis are comparable to those of more active swimmers, (e.g. fish white skeletal muscle, Table 2), illustrating the large metabolic potential of C. amurensis foot tissue.

Corbula amurensis respiration rates coupled with the enhanced metabolic potential of high MDH activities leads us to hypothesize that these clams maintain elevated cellular machinery to increase metabolic activity so that they can rapidly process food when it becomes available and rapidly respond to changing salinity. One clam in the fluctuating-salinity acclimation group had an order of magnitude higher respiration rate than any other clams in our study. This clam was not exceptional in any other way, but perhaps on a cellular level this clam was actually using its metabolic machinery at maximal flux rates. In clams with low metabolic rates that maintain high $\mathrm{MDH}$ activities, we hypothesize that in nature metabolic flux is limited by availability of metabolic substrate and not metabolic enzyme activity; thus Corbula may be able to rapidly oxidize food when it is available. The potential ability of these clams to modulate their respiration rates has implications for estimation of their impact in the natural environment since the energetic demands can vary over an order of magnitude among individual clams.

In sum, our results indicate that Corbula amurensis have increased metabolic demand at high salinity, that the increased metabolic demand is likely associated with hyposmoregulation, and that the clams compensate for the increased metabolic demand by filtering at a higher rate. Our acclimation studies were performed under conditions of salinity that were intended to elicit maximal physiological variations in $C$. amurensis. In the northern SFE, salinity at some locations goes to 0 , a regime investigated in pilot experiments in which clams held in freshwater (not shown here) resulted in $100 \%$ mortality. Examination of the metabolic potential immediately following collection of $C$. amurensis acclimatized to natural salinity variation is an important next step to understand how changes in water management practices could alter the impact these clams have on the pelagic food web.
Acknowledgements. This work was supported by a State of California Interagency Ecological Program grant to W.J.K. and J.H.S. Ammonium excretion data were collected by V. Greene and A. Kleckner. We greatly appreciate the following individuals for assisting in specimen collection and logistic support throughout the study: A. Cayenne, C. Tomas Miranda, A. Tagmount, S. Lefebvre, N. Miller, T. Waterson, H. Medina, and D. Bell.

\section{LITERATURE CITED}

Alpine AE, Cloern JE (1992) Trophic interactions and direct physical effects control phytoplankton biomass and production in an estuary. Limnol Oceanogr 37:946-955

Arthur JF, Ball MD (1979) Planktonic chlorophyll dynamics in the northern San Francisco Bay and Delta. In: Conomos TJ (ed) San Francisco Bay: the urbanized estuary. Pacific Division, American Association for the Advancement of Science, San Francisco, CA, p 265-285

Carlton JT, Thompson JK, Schemel LE, Nichols FH (1990) Remarkable invasion of San Francisco Bay (California, USA) by the Asian clam Potamocorbula amurensis. I. Introduction and dispersal. Mar Ecol Prog Ser 66:81-94

> Chaparro OR, Montiel YA, Segura CJ, Cubillos VM, Thompson RJ, Navarro JM (2008) The effect of salinity on clearance rate in the suspension-feeding estuarine gastropod Crepipatella dilatata under natural and controlled conditions. Estuar Coast Shelf Sci 76:861-868

Childress JJ, Somero GN (1979) Depth-related enzymic activities in muscle, brain, and heart of deep-living pelagic marine teleosts. Mar Biol 52:273-283

Dahlhoff EP, Stillman JH, Menge BA (2002) Physiological community ecology: variation in metabolic activity of ecologically important rocky intertidal invertebrates along environmental gradients. Integr Comp Biol 42:862-871

- Deaton LE (1987) Epithelial water permeability in the euryhaline mussel Geukensia demissa: decrease in response to hypoosmotic media and hormonal modulation. Biol Bull (Woods Hole) 173:230-238

> Deaton LE (1992) Osmoregulation and epithelial permeability in two euryhaline bivalve molluscs: Mya arenaria and Geukensia demissa. J Exp Mar Biol Ecol 158:167-177

Feely RA, Doney SC, Cooley SR (2009) Ocean acidification: present conditions and future changes in a high- $\mathrm{CO}_{2}$ world. Oceanography 22(4):36-47

Fernández-Reiriz MJ, Navarro JM, Labarta U (2005) Enzymatic and feeding behaviour of Argopecten purpuratus under variation in salinity and food supply. Comp Biochem Physiol A 141:153-163

Feyrer F, Nobriga ML, Sommer TR (2007) Multidecadal trends for three declining fish species: habitat patterns and mechanisms in San Francisco Estuary, California, USA. Can J Fish Aquat Sci 64:723-734

Gardner JPA, Thompson RJ (2001) The effects of coastal and estuarine conditions on the physiology and survivorship of the mussels Mytilus edulis, $M$. trossulus and their hybrids. J Exp Mar Biol Ecol 265:119-140

Gaspar BM, Santos NM, Vasconcelos P, Monteiro CC (2002) Shell morphometric relationships of the most common bivalve species (Mollusca: Bivalvia) of the Algarve coast (southern Portugal). Hydrobiologia 477:73-80

> González RR, Quiñnones RA, Quiroga E, Sellanes J (2008) Aerobic and anaerobic enzymatic activities of Calyptogena gallardoi (Vesicomyidae): a clam associated with methane cold seeps off Chile. J Mar Biol Assoc UK 88: 983-986 
Goward CR, Nicholls DJ (1994) Malate dehydrogenase: a model for structure, evolution, and catalysis. Protein Sci 3: 1883-1888

Grandón MA, Barros JA, Gonzalez RR (2008) Metabolic characterization of Diplodon chilensis (Gray, 1828) (Bivalvia: Hyriidae) exposed to experimental anoxia. Rev Biol Mar Oceanogr 43:531-537 (in Spanish with English abstract)

Hilden S, Hokin L (1976) Coupled $\mathrm{Na}^{+}-\mathrm{K}^{+}$transport in vesicles containing a purified ( $\mathrm{NaK})$-ATPase and only phosphatidyl choline. Biochem Biophys Res Commun 69: 521-527

Hummel H, Bogaards RH, Bachelet G, Caron F, Sola JC, Amiard-Triquet C (2000) The respiratory performance and survival of the bivalve Macoma balthica (L.) at the southern limit of its distribution area: a translocation experiment. J Exp Mar Biol Ecol 251:85-102

Kilham SS, Kreeger DA, Lynn SG, Goulden CE, Herrera L (1998) COMBO: a defined freshwater culture medium for algae and zooplankton. Hydrobiologia 377:147-159

Kim WS, Huh HT, Huh SH, Lee TW (2001) Effects of salinity on endogenous rhythm of the Manila clam, Ruditapes philippinarum (Bivalvia: Veneridae). Mar Biol 138:157-162

Kimmerer WJ (2002a) Effects of freshwater flow on abundance of estuarine organisms: physical effects or trophic linkages? Mar Ecol Prog Ser 243:39-55

Kimmerer WJ (2002b) Physical, biological, and management responses to variable freshwater flow into the San Francisco Estuary. Estuaries 25:1275-1290

Kimmerer WJ, Orsi JJ (1996) Causes of long-term declines in zooplankton in the San Francisco Bay estuary since 1987. In: Hollibaugh JT (ed) San Francisco Bay: the ecosystem. American Association for the Advancement of Science, San Francisco, CA, p 403-424

Kimmerer WJ, Gartside E, Orsi JJ (1994) Predation by an introduced clam as the likely cause of substantial declines in zooplankton of San Francisco Bay. Mar Ecol Prog Ser 113:81-93

Kimmerer WJ, Gross ES, MacWilliams ML (2009) Is the response of estuarine nekton to freshwater flow in the San Francisco Estuary explained by variation in habitat volume? Estuar Coast Mar Sci 32:375-389

Knowles N, Cayan DR (2002) Potential effects of global warming on the Sacramento/San Joaquin watershed and the San Francisco estuary. Geophys Res Lett 29:1891 doi: 10.1029/2001GL014339

Mao Y, Zhou Y, Yang H, Wang R (2006) Seasonal variation in

Editorial responsibility: Peter Beninger,

Nantes, France metabolism of cultured Pacific oyster, Crassostrea gigas, in Sanggou Bay, China. Aquaculture 253:322-333

May RM (1973) Stability and complexity in model ecosystems. Princeton University Press, Princeton, NJ

Mount J, Twiss R (2005) Subsidence, sea level rise, and seismicity in the Sacramento-San Joaquin Delta. S Francisco Estuar Watershed Sci 3:5

Moyle PB (2008) The future of fish in response to large-scale change in the San Francisco Estuary, California. Am Fish Soc Symp 64:357-374

> Nakamura Y, Hashizume K, Koyama K, Tamaki A (2005) Effects of salinity on sand burrowing activity, feeding, and growth of the clams Mactra veneriformis, Ruditapes (= Tapes) philippinarum, and Meretrix lusoria. J Shellfish Res 24:1053-1059

$>$ Navarro JM (1988) The effects of salinity on the physiological ecology of Choromytilus chorus (Molina, 1782) (Bivalvia: Mytilidae). J Exp Mar Biol Ecol 122:19-33

Nichols FH, Thompson JK, Schemel LE (1990) Remarkable invasion of San Francisco Bay (California, USA) by the Asian clam Potamocorbula amurensis. II. Displacement of a former community. Mar Ecol Prog Ser 66:95-101

Orsi JJ, Mecum WL (1996) Food limitation as the probable cause of a long-term decline in the abundance of Neomysis mercedis the opossum shrimp in the Sacramento-San Joaquin estuary. In: Hollibaugh JT (ed) San Francisco Bay: the ecosystem. American Association for the Advancement of Science, San Francisco, CA, p 375-401

Roos M (1989) Possible climate change and its impact on water supply in California. Oceans 89:247-249

Siebenaller JF, Somero GN (1982) The maintenance of different enzyme activity levels in congeneric fishes living at different depths. Physiol Zool 55:171-179

Sommer T, Armor C, Baxter R, Breuer R and others (2007) The collapse of pelagic fishes in the upper San Francisco Estuary. Fisheries 32:270-277

Stillman JH, Dahlhoff EP, Somero GN (1996) Biochemical indicators of physiological state in the intertidal mussel Mytilus californianus. Physiologist 37:921

Strayer DL (2010) Alien species in fresh waters: ecological effects, interactions with other stressors, and prospects for the future. Freshw Biol 55:152-174

Werner I, Hollibaugh JT (1993) Potamocorbula amurensis: comparison of clearance rates and assimilation efficiencies for phytoplankton and bacterioplankton. Limnol Oceanogr 38:949-964

Submitted: April 28, 2010; Accepted: October 26, 2010

Proofs received from author(s): December 2, 2010 